УДК $630 * 165$

ОЦЕНКА БИОГЕНЕТИЧЕСКОГО РАЗНООБРАЗИЯ РАСТЕНИЙ

ПЛОДОВО-ЯГОДНЫХ КУЛЬТУР В ГЕНОФОНДЕ. СОЗДАНИЕ НОВЫХ СОРТОВ

Гаджиева А.Ф., Ахундова Н.И., Гасанов Н.А.

Институт генетических ресурсов Наџиональной академии наук Азербайджана, Бакy,e-mail: gadjieva-aynura@rambler.ru

Получены результаты по выявлению фенотипического и геноцитологического разнообразия двух растительных плодово-ягодных культур (земляника и унаби). Образцы генофондных плантаций различаются по фенотипу, генотипу, морфологическим данным (роста, развития), биохимическим показателям. Цель исследования - обнаружение особенности величины, массы плодов, развития (органогенез) цитологических межсортовых различий. Исследование различия и активности синтеза ДНК, структуры ДНК хроматина использовалось для получения и изучения новых местных селекционных образцов. При получении новых гибридных плодов ускорялся селекционный процесс. Велась работа по получению новых гибридов между мелкоплодными местными сортами и крупноплодными интродуцентами. Отбирались новые образцы, сочетающие положительные признаки родительских форм (крупноплодность, отсутствие болезней). Величина и масса плодов при гибридизации колебалась и состояла из трех групп по величине: промежуточная при $\mathrm{h}=0$, мелкие при $\mathrm{h}>0$ и крупноплодные при $\mathrm{h}<0$. Установлено, что часто большая часть гибридов относилась к промежуточной и составляла $50 \%$ гибридов, мелкоплодные гибриды составили 32-37\% и крупноплодные 15-17\%. Установлены межсортовые различия в активности синтеза ДНК, структуре хроматина и его упаковке. Показан факт меньшего содержания ДНК и лабильной фракции у стародавних сортов унаби по сравнению с новыми сортами. При промежуточном характере содержания ДНК и лабильной фракции ДНК хроматина занимает промежуточное положение. Можно говорить о разном фенотипе и генотипе. Выявлена связь между повышенным содержанием ДНК и лабильной фракции ДНК у засухо- и солеустойчивых сортов земляники. Можно говорить о разных генотипах у контрольных и стресоустойчивых сортов. Установлен полиморфизм по числу хромосом у обеих культур. Встречаются сорта диплоидные, триплоидные, тетраплоидные и гексаплоидные. Используя все эти данные, созданы и отобраны 4 новых сорта унаби и 14 стресоустойчивых сорта земляники.

Ключевые слова: генофонд, земляника, унаби, фенотип, генотип, хромосомный комплекс, новые сорта

\title{
ASSESSMENT OF BIOGENETIC DIVERSITY OF PLANTS OF FRUIT AND BERRY CROPS IN THE GENE POOL. CREATION OF NEW VARIETIES
}

\author{
Gadzhieva A.F., Akhundova N.I., Gasanov N.A. \\ Genetic Resources Institute of ANAS, Baku, e-mail: gadjieva-aynura@rambler.ru
}

\begin{abstract}
Results onthe identification of the phenotypic and geno-cytological diversity of two plant fruit and berry crops (strawberry and Ziziphus)were obtained.Samples of gene pool plantations differ in phenotype, genotype, morphological data (growth of development), and biochemical indicators. The purpose of the study was to reveal the peculiarities of the size, weight of fruits, development (organogenesis) of cytological intervarietal differences. The study of the difference and activity of DNA synthesis, the structure of DNA of chromatin was usedin order to obtain and study new local breeding samples. When new hybrid fruits were obtained, the selection process was accelerated. Work was carried outto obtain new hybrids between small-fruited local varieties and large-fruited introduced species. New samples were selected, combining positive signs of parental forms (large-fruited, absence of diseases). The size and weight of fruits during hybridization can fluctuate and consist of 3 groups in size: intermediate at $h=0$, small at $\mathrm{h}>0$ and large-fruited at $\mathrm{h}<0$. It was found that often most of the hybrids belonged to the intermediate group and accounted for $50 \%$ of the hybrids, small-fruited hybrids accounted for $32-37 \%$ and large-fruited 15 $17 \%$. Intervarietal differences in the activity of DNA synthesis, the structure of chromatin, and its packing were established. The fact of a lower content of DNA and labile fraction in old varieties of Ziziphus in comparison with new varieties was shown. Under an intermediate character, the content of DNA and the labile fraction of DNA of chromatin occupythe intermediate position. We can talk about a different phenotype and genotype. Relationship between the increased DNA content and the labile DNA fraction in drought and salt tolerant strawberry varieties was revealed. We can talk about different genotypes in control and stress-resistant varieties. Polymorphism in the number of chromosomes in both cultures was established. There are diploid, triploid, tetraploid and hexaploid varieties. Using all these data, 4 new unabi varieties and 14 stress-resistant strawberry varieties were created and selected.
\end{abstract}

Keyword: gen fund, strawberry, Ziziphus, phenotype, genetype, chromosome complex, selection

В настоящей статье ставилась задача не ограничиваться феноизучением, темпами роста и развития образцов в генофонде, но изучить образцы с применением молекулярно-генетических методов. Это позволит дать цитогенетическую характеристику, выявить генотип, что особенно важно при создании новых сортов [1, 2]. Образцы земляники (Fragaria ananassa Duch) и унаби (Ziziphus jujube Mill.) в собранном генофонде Института генетических ресурсов НАН Азербайджана отличаются рядом свойств, величиной и качествами ягод и плодов, тем- 
пами роста и развития, биохимическими показателями [3-6].

Учитывая особенности климата республики с засушливым летом и наличием засоленных почв, отбор соле- и засухоустойчивых сортов земляники имеет большое значение [7-9]. Но только по фенопоказателям сортов невозможно выделить стрессоустойчивые формы. Использование цитогенетического анализа, содержания ДНК, структуры ДНК хроматина, показателя хромосомного комплекса выявило проявление генотипа. Анализы генотипов и фенотипов различных образцов земляники помогут выявить разницу между стрессоустойчивыми и стрессонеустойчивыми сортами $[9,10]$. Эти показатели можно рассматривать как генетические маркеры по выявлению стрессустойчивых сортов земляники в определенных экологических зонах.

Унаби растет в республике издавна, но местные сорта и формы в основном суховатые, невысокого вкуса. Последнее время с использованием ряда старых методик в сочетании с генетико-цитологическими исследованиями получены новые, крупноплодные сорта и гибриды [11].

Изучение фено- и генетикоцитологического разнообразия образцов культур: земляники и унаби, отбор новых форм. Применение в селекционных работах наряду с традиционными методами цитогенетических анализов, которые в последнее время приобретают большое значение в ряде областей биологии, своевременно.

\section{Материалы и методы исследования}

Работа проводилась на Апшеронской опытной базе Института генетических ресурсов НАН Азербайджана. Работа заключалась в изучении фенотипа и генотипа образцов земляники и унаби в генофонде, в проведении цитогенетических исследований, особенностей хромосомного комплекса.

Контроль генетической устойчивости к солевому стрессу $(0,2 \mathrm{M} \mathrm{NaCl})$ и осмотическому стрессу (ПЕГ-0,5 атм) заключался в изучении восстановительных особенностей земляники, после использования стресс-агентов. Исследования включали данные по биосинтезу ДНК и структуры ДНК хроматина у различных сортов. Эти данные показатели можно рассматривать как генетические маркеры по выявлению стрессоустойчивых сортов земляники $[8,9]$. Параллельно с растениями земляники наряду с фенои- зучением сортов и форм велись с унаби также исследования по содержанию ДНК, структуры ДНК хроматина, его упаковки, жаровыносливости.

Содержание ДНК определяли спектрофотометрически при длине волны 270 и 290 мм.

Метод фракционирования ДНК проводился по принципу ступенчатого воздействия на хроматин разной ионной силы, что позволяет разделить клеточную ДНК на лабильную, стабильную и остаточную фракции. Определение содержания отдельных фракций ДНК проводилось на свежем листовом материале земляники и унаби методом центрифугирования (500-2000 об.) и дальнейшим спектрофотометрированием. Образцы просматривались на спектрофотометре.

Характер наследования признаков гибридами определялись по соотношению среднего показателя гибрида к среднему показателю родителей по формуле

$$
h=\frac{F 1-M F}{H F-M F},
$$

где $h$ - степень наследования; $F 1$ - среднее значение признаков гибридного поколения; $H F$ - значение признаков лучшего родителя; $M F$ - среднее значение признаков обоих родителей.

Цитологические анализы земляники и унаби проводились по общепринятой для плодовых культур методике [12].

\section{Результаты исследования и их обсуждение}

У неустойчивых к стрессам сортам земляники Дильбер и Гибрид 237 отмечено ослабление синтеза ДНК на $45 \%$. У стрессоустойчивых сортов Берюлевская, Лермонтовская, Кавальер, Реддекоут по содержанию ДНК, отмечено увеличение этого показателя почти на 50 \%. У высоко- и среднеустойчивых сортов отмечено увеличение остаточной прочной связанной фракции ДНК и почти трехкратное уменьшение этого показателя у стрессонеустойчивых сортов (табл. 1). А остаточная фракция редко дает такие явные результаты. Проявление генотипа у некоторых сортов земляники позволяет выявить варьирования локусов изменчивости признаков.

Образцы генофондной коллекции унаби также различаются фенотипами величиной плодов, темпами роста и развития, генотипом. 
Таблица 1

Содержание и структурно-функциональное состояние ДНК хроматина в зависимости от стрессоустойчивости у сортов и форм крупноплодной земляники

\begin{tabular}{|c|c|c|c|c|c|c|c|}
\hline \multirow[t]{2}{*}{ № } & \multirow[t]{2}{*}{ Сорта и формы } & \multicolumn{5}{|c|}{ ДНК / фракции мг/100 г } & \multirow{2}{*}{$\begin{array}{c}\text { Устойчивость } \\
\text { сортов к стрессам } \\
\end{array}$} \\
\hline & & 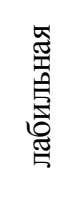 & 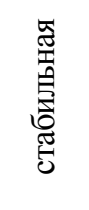 & 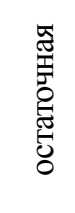 & 兽 & 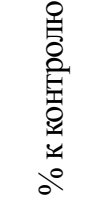 & \\
\hline \multirow[t]{3}{*}{1} & Лермонтовская & 0,64 & 0,72 & 1,59 & 2,95 & - & Высокоустойчивый \\
\hline & $\mathrm{NaCE}$ & 1,46 & 1,42 & 3,02 & 5,90 & $+75,9$ & \\
\hline & PEQ & 0,76 & 1,18 & 2,45 & 4,40 & $+49,1$ & \\
\hline \multirow[t]{3}{*}{2} & Кавальер & 2,88 & 2,19 & 1,62 & 6,69 & - & Высокоустойчивый \\
\hline & $\mathrm{NaCE}$ & 3,43 & 3,52 & 2,65 & 9,60 & $+43,4$ & \\
\hline & PEQ & 3,85 & 4,73 & 2,76 & 11,34 & $+69,5$ & \\
\hline \multirow[t]{3}{*}{3} & Берюлевская & 1,66 & 0,79 & 5,58 & 8,03 & - & Среднеустойчивый \\
\hline & $\mathrm{NaCE}$ & 1,97 & 1,64 & 6,09 & 9,70 & +22 & \\
\hline & PEQ & 2,39 & 1,09 & 6,87 & 10,35 & +29 & \\
\hline \multirow[t]{3}{*}{4} & Реддекоут & 2,46 & 2,93 & 1,01 & 6,39 & - & Среднеустойчивый \\
\hline & $\mathrm{NaCE}$ & 2,53 & 3,77 & 1,33 & 7,63 & $+19,4$ & \\
\hline & PEQ & 1,28 & 1,06 & 0,58 & 7,63 & -55 & Засухонеустойч. \\
\hline \multirow[t]{3}{*}{5} & Дильбер & 9,09 & 2,14 & 1,79 & 13,02 & - & неустойчивый \\
\hline & $\mathrm{NaCE}$ & 8,51 & 2,87 & 1,19 & 12,57 & -4 & \\
\hline & PEQ & 8,15 & 2,05 & 1,16 & 11,36 & $-12,7$ & \\
\hline \multirow[t]{3}{*}{6} & Гибрид 237 & 6,40 & 2,07 & 1,06 & 9,53 & - & неустойчивый \\
\hline & $\mathrm{NaCE}$ & 4,18 & 2,20 & 0,66 & 7,04 & $-26,5$ & \\
\hline & PEQ & 3,59 & 1,33 & 0,33 & 5,25 & $-45,0$ & \\
\hline
\end{tabular}

Исследованиями установлено, что местные сорта и формы унаби представляют интерес при создании гибридов в качестве источника устойчивости к болезням и вредителям, засухоустойчивости, интродуценты являются донорами крупноплодности, высоких диетических качеств [13]. Результат анализов 200 гибридных саженцев унаби, полученных гибридизацией между растениями местными мелкоплодными웅 и крупноплодными интродуцентами $\hat{O}^{2}$, свидетельствуют о сложном характере наследования величины плодов. Данные результаты объясняются гетерозиготностью родительских компонентов и полигенным характером изучаемых признаков (табл. 2). Примерно у $50 \%$ полученных гибридных образцов отмечен промежуточный характер наследования величины плодов между местными мелкоплодными и крупноплодными интродуцентами, степень доминирования $\mathrm{h}=0$, эти показатели колеблются $0,11-0,18$. У $33-37 \%$ гибридов отмечено частичное или полное доминирование мел- коплодной материнской формы, где $\mathrm{h}$ колебалось от $-0,1$ до $-0,54$ и $15-17 \%$ новых гибридных сеянцев имело $\mathrm{h}$ (доминирование отцовских крупноплодных сортов в интервале от +0.55 до +0.18 ). В одних и тех же комбинациях скрещивания отмечено расщепление гибридов по величине, массе плодов на промежуточное наследование, наследование отцовского или материнского показателя, т.е. 3 степени $(\mathrm{h}=0, \mathrm{~h}>0, \mathrm{~h}<0)$.

Исследование у унаби метаболизма ДНК по образцам в генофонде велось в двух направлениях:

1) исследование содержания ДНК у гибридов унаби, структуры ДНК хроматина, его упаковки;

2) изучение генома унаби у стародавних и новых селекционных сортов в коллекции.

По первому направлению работы получены свидетельства усиления механизма редупликации ДНК и образования копий генов у гибридных растений при частичном или полном доминировании величины плодов одной из родительских форм [1]. 
Таблица 2

Характеристика наследования массы плодов у гибридов унаби

\begin{tabular}{|c|c|c|c|c|c|c|c|}
\hline \multirow[t]{2}{*}{$\mathrm{N}$} & \multirow[t]{2}{*}{ Гибриды } & \multirow{2}{*}{$\begin{array}{l}\text { Комбинация } \\
\text { скрещивания } \\
\text { (сорта) }\end{array}$} & \multicolumn{3}{|c|}{$\mathrm{M} \pm \mathrm{M}(\mathrm{\Gamma})$} & \multirow{2}{*}{$\begin{array}{c}\text { h степень } \\
\text { домини } \\
\text { рования }\end{array}$} & \multirow{2}{*}{$\begin{array}{c}\text { Характер } \\
\text { наследования }\end{array}$} \\
\hline & & & $\begin{array}{c}\text { Мелко } \\
\text { плодный } \\
\text { q }\end{array}$ & Гибрид F & \begin{tabular}{c} 
Крупно \\
плодный \\
\multirow{\lambda}{\lambda}{}
\end{tabular} & & \\
\hline 1 & $1 / 4$ & $\begin{array}{l}\text { +мелккоплодХ } \\
{ }^{\wedge} \text { Таян-цзао }\end{array}$ & $3,5 \pm 0,12$ & $8,6 \pm 0,27$ & $19,0 \pm 0,46$ & $-0,37$ & $\begin{array}{c}\text { Част. домин. } \\
\text { Мелкоплод. ро-ля }\end{array}$ \\
\hline 2 & $6 / 18$ & $\begin{array}{l}\text { कмелкоплодХ } \\
\text { ○ТТян-цзао }\end{array}$ & $3,5 \pm 0,12$ & $12 \pm 0,47$ & $19,0 \pm 0,46$ & 0,18 & Промежуточное \\
\hline 3 & 9/1 & $\begin{array}{l}\text { कмелкоплодХ } \\
{ }^{\uparrow} \text { Таян-цзао }\end{array}$ & $3,5 \pm 0,12$ & $10,3 \pm 0,36$ & $19,0 \pm 0,46$ & $-0,12$ & Промежуточное \\
\hline 4 & $9 / 2$ & 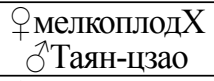 & $3,5 \pm 0,12$ & $7,0 \pm 0,27$ & $19,0 \pm 0,46$ & $-0,54$ & Домин. мелкоп. р-ля \\
\hline 5 & $13 / 1$ & $\begin{array}{l}\text { †мелкоплодХ } \\
\text { § Таян-цзао }\end{array}$ & $3,5 \pm 0,12$ & $8,5 \pm 0,46$ & $19,0 \pm 0,46$ & $-0,35$ & Домин. мелкоп. р-ля \\
\hline 6 & $3 / 2$ & $\begin{array}{l}\text { OмелкоплодХ } \\
\text { †'Юбилейный }\end{array}$ & $3,5 \pm 0,12$ & $7,0 \pm 0,69$ & $8,0 \pm 0,31$ & $+0,55$ & Домин. круп. р-ля \\
\hline 7 & $4 / 8$ & $\begin{array}{l}\text { OмелкоплодХ } \\
\text { क'Юбилейный }\end{array}$ & $3,5 \pm 0,12$ & $6,3 \pm 0,31$ & $8,0 \pm 0,51$ & 0,24 & Промежуточное \\
\hline 8 & $3 / 2$ & $\begin{array}{l}\text { омелкоплодХ } \\
\text { †'Юбилейный }\end{array}$ & $3,5 \pm 0,12$ & $8,0 \pm 0,21$ & $8,0 \pm 0,51$ & $+1,40$ & Домин. круп. р-ля \\
\hline 9 & $2 / 1$ & $\begin{array}{l}\text { ОмелкоплодХ } \\
\text { ОДДаргомский }\end{array}$ & $3,5 \pm 0,12$ & $8,9 \pm 0,21$ & $17,5 \pm 0,51$ & $-0,22$ & $\begin{array}{c}\text { Част. домин. } \\
\text { Мелкоплод. ро-ля }\end{array}$ \\
\hline 10 & $15 / 1$ & $\begin{array}{l}\text { ОмелкоплодХ } \\
\text { ОДаргоский }\end{array}$ & $3,5 \pm 0,12$ & $11,3 \pm 0,16$ & $17,5 \pm 0,51$ & 0,11 & Промежуточное \\
\hline
\end{tabular}

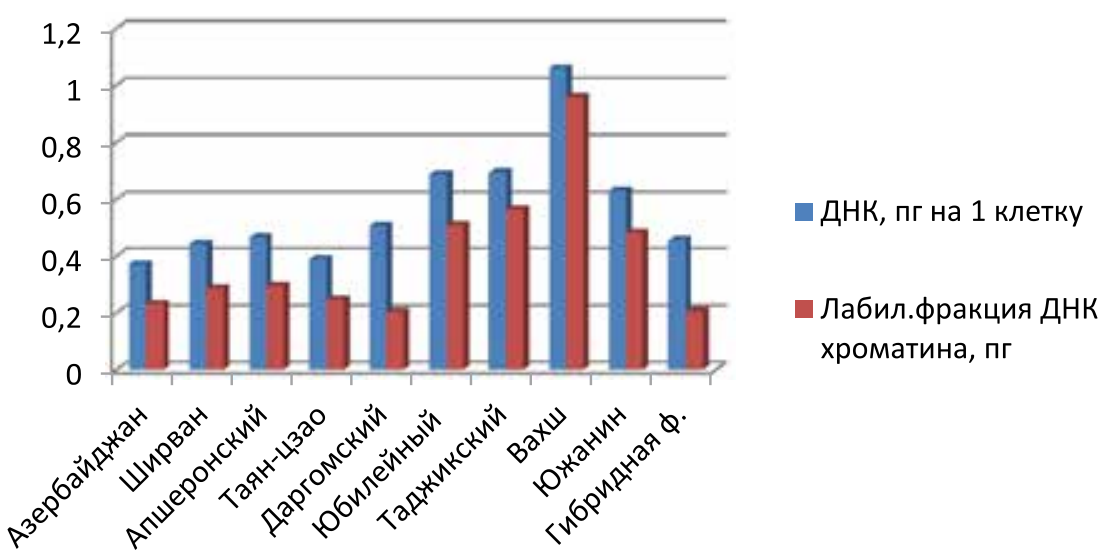

Синтез ДНК и лабильной фракиии ДНК в клетках стародавних и новых сортов растений зизифуса

При промежуточном наследовании величины плодов у гибридов часто содержание ДНК, лабильной фракции ДНК хроматина занимало промежуточное положение. При доминировании величины плодов одной из родительских форм процесс метаболизма нуклеиновых кислот идет в основном как за счет увеличения лабильной фракции ДНК, так и более высокого его долевого содержания.

По второму направлению получены данные, свидетельствующие, что у местных стародавних сортов и стародавнего со- рта Таян-цзао содержание ДНК в 1,5-2 раза ниже, чем у новых средних крупноплодных сортов, часто гибридного происхождения. Предполагается наличие механизмов регуляции ДНК за счет сброса повторов в геноме. У новых часто гибридных сортов содержание ДНК в клетке приводит к образованию копий генов или повторностей. У старых сортов показатель изменчивости имеет малый разброс 1,6-2,1\%, у новых изменчивость геномов имеет высокую амплитуду колебания от $0,7 \%$ у нового сорта Даргомский, до 12,6\% еще более молодого сорта Вахш. 
Как видно из рисунка, местные сорта характеризуются и меньшим количеством ДНК на клетку. Эти данные говорят о нестабильности генома новых сортов, их общей пластичности, изменчивости по сравнению со старыми. По содержанию ДНК в клетках стародавние сорта уступают новым сортам. Аналогичный процесс наблюдается по структурно-функциональному состоянию ДНК хроматина. Содержание лабильной фракции ДНК хроматина колеблется у стародавних сортов (-0,062 пг) в клетке, у новых сортов этот показатель характеризуется высокой амплитудой колебания с разницей $(+0,277$ пг) у новых сортов.

Показатель активности генетического аппарата новых сортов характеризуется высоким разбросом в сравнении со стародавними сортами.

Исследования хромосомного комплекса различных образцов, как земляники, так и унаби свидетельствуют о полиморфизме этого показателя. Коллекции и земляники, и унаби включали основное число диплоидных сортов $(2 \mathrm{n}=24)$ унаби, триплоидные $(2 \mathrm{n}=36)$, у нового сорта Даргомский наряду с 24 хромосомами отмечено появление $2 \mathrm{n}=12,28,30,36$ (1 клетка) и 2 клетки $2 \mathrm{n}=48$. Аналогичная картина полиморфизма этого показателя 2n отмечена у земляники основное число $2 \mathrm{n}=42$ (гексаплоид), обнаружены образцы с клетками $2 \mathrm{n}=14,28$, 56 этих культур.

Исследованиями выявлено фено- и цитогенетическое разнообразие (полиморфизм) образцов генофондов земляники и унаби.

Модификация структуры хроматина происходит за счет распределения фракций хроматина, их содержания, доли, особенно лабильной фракции, являющейся маркером сортов, у гибридов земляники при ее регуляции засухо- и солеустойчивости $[7,11,14]$.

Были изучены различные сорта и формы земляники и унаби, что свидетельствовало о существенных различиях, обусловленных генетическими особенностями образцов. Выявлена связь активизации ДНК со стрессустойчивостью, увеличение лабильной фракции, эухроматизации хроматина у стрессоустойчивых сортов земляники. Это положение актуально для республики с ее высокими летними температурами, засухами, наличием засоленных земель. Отмечены модификации ДНК хроматина у стрессоустойчивых и неустойчивых сортов земляники: резкое повышение содержания лабильной фракции у первых и снижение этого показателя у вторых.
Используя данные биоцитогенетических анализов, авторы создали новые, перспективные сорта, адаптированные к местным условиям, изучены стрессоустойчивые сорта земляники, которые могут заменить стрессонеустойчивые сорта. Используя различные методы биологии, соавторы пополнили генофонд новыми сортами, которые заменили старые, стрессонеустойчивые. Также авторами статьи выведены два новых, крупноплодных сорта унаби, переданные в Госсорткомиссию.

\section{Заключение}

1. Генофонд земляники и унаби состоит из многочисленных образцов, имеющих разный фенотип, генотип, различные темпы роста и развития.

2. Коллекция земляники и унаби полиморфна по содержанию ДНК, лабильной фракции ДНК хроматина, по комплексу хромосом. У одного сорта встречаются ди-, три-, тетра-, гексаплоидные экземпляры. Чаще всего встречаются основные числа у земляники $2 \mathrm{n}=42$ (гексаплоид), у унаби основное число $2 \mathrm{n}=24$ (диплоид).

3. Степень доминирования величины плодов (масса, длина, диаметр) в коллекции очень разнообразна. При гибридизации крупноплодных и мелкоплодных плодов гибриды характеризуются в основном промежуточным доминированием $(\mathrm{h}=0)$, но отмечено частичное появление гибридов, схожих с мелкоплодным материнским $(\mathrm{h}<0)$ и реже с крупноплодным отцовским $(\mathrm{h}>0)$ типом. В одной комбинации скрещивания часто возникают три группы гибридов.

4. Установлено изменение нуклеинового метаболизма (содержание ДНК, структуры ДНК хроматина, упаковки хроматина) у стрессоустойчивых образцов земляники и гибридных форм унаби с различным генотипом стародавних и новых сортов. Очевидно, существуют механизмы регуляции, выражающиеся в сбросе повторов.

5. Выделены и отобраны различными путями (отбор, гибридизация, по итогам изучения структурно-функционального состояния ДНК, упаковки хроматина у обеих культур), новые формы с рядом положительных признаков, адаптированные к местным условиям.

\section{Список литературы / References}

1. Разин С.В., Быстрицкий А.А. Хроматин; упакованный геном. БИНОМ Лаб. знаний. 2013. 172 с.

Razin S.V., Bystritskiy A.A. Chromatin; packed genome. BINOM Lab. znaniy. 2013. 172 p. (in Russian). 
2. Шабанова Е.А. Цитогенетический анализ как метод оценки стабильности генетического материала местных древесных растений в культуре тканей // Состояние лесов и актуальные проблемы лесоуправления. 2013. С. 234-237.

Shabanova E.A. Cytogenetic analysis as a method for assessing the stability of the genetic material of local woody plants in tissue culture // Sostoyaniye lesov i aktual'nyye problemy lesoupravleniya. 2013. P. 234-237 (in Russian).

3. Дубровский М.Л., Лыжин А.С., Ван-Ункан Н.Ю Получение и отбор генотипов плодово-ягодных культур с измененным уровнем плоидности. Методика Мичуринск. ВНИИ ГиСпР, 2013. 52 с.

Dubrovsky M.L., Lyzhin A.S. Van-Unkan N.Yu. Obtaining and selection of genotypes of fruit and berry crops with an altered level of ploidy. Methodology Michurinsk. VNII GiSpR, 2013. 52 p. (in Russian).

4. Межнина О.А., Урбанович О.Ю. Изучение генетического разнообразия земляники садовой (Fragariya ananassa L.) выращиваемой в Белоруссии. Молекулярная и прикладная генетика. Минск, 2015. сб. т. 19. С. 53-58.

Meznina O.A., Urbanovich O.Yu. Study of the genetic diversity of garden strawberries (Fragariya ananassa L.) grown in Belarus. Molekulyarnaya i prikladnaya genetika. Minsk, 2015. v. 19. P. 53-58 (in Russian).

5. Сандалова М.В. Перспективы селекции ремонтантных и нейтральнодневных сортов земляники садовой// Аграрная наука - сельскому хозяйству. 2013. С. 203-205.

Sandalova M.V. Prospects for breeding remontant and neutral day varieties of garden strawberries // Agrarnaya nauka sel'skomu khozyaystvu. 2013. P. 203-205 (in Russian).

6. Zhu J.K. Salt and drought stress signal transdriction in plant. Anny Rev. plant. 2002. V. 52. P. 347-373.
7. Alone C.O. Variation and heritability of sexsteen eharactor in west Afrikan okra. Abelmschus carllef stern plant Breed un seed scu. 2012. V. 66. P. 51-62.

8. Barsa A.S. Gene expression in relation to salt tolerance in stress induced gene expression in plant. Harvard Academic Publishers, Swerland. 1994. P. 61-87.

9. Luhua S., Hegie A., Suzuku N., Shilov L. Luo etall Luking gens jf unknown function with abiotik stress responses by high-through rout phenotype screening. Phisiol. Plant. 2013. V. 148. № 322-333.

10. Prasch C.M., Sonnewald U. Simultaneous application of heat, drought, and virus to Arabidopsis plants reveals significant shifts in signaling networks. Plant phisiralrab. 2013. V. 162 № 4. P. 1849-1866. DOI: 10.1104/pp.113.221044.

11. Scaldaferro M.A., GraeleMeuro, Moskone. Heterochromatin type amount and distribion in wild species of chili pepper gen. Recourse and Crp Eve. 2013. V. 60. № 2. P. 693-709.

12. Рыбин В.А. Цитологический метод в селекции плодовых. М.: Колос, 1967. 216 с.

Rybin V.A. Cytological method in fruit breeding. Ed. M.: Kolos, 1967. 216 p. (in Russian).

13. Ziu M.J., Zhao Z.M. Germplasmresburces and production of jujube in China. ActaHort 840. 2009. P. 25-31.

14. Шаптуренко М.Н., Тарутина Л.А., Мишин Л.А., Кильчевский А.В., Хотылева Л.В. Девергенция ДНК как критерий отбора исходного материала перца сладкого при селекции на гетерозис // Генетика. 2014. Т. 50. № 2. C. $138-146$.

Shanturenko M.N., Tarutin L.A., Mishin L.A., Kilchevsky A.V., Khotyleva L.V. DNA deviation as a criterion for the selection of the starting material of sweet pepper in breeding for heterosis // Genetika. 2014. V. 50. № 2. P. 138-146 (in Russian). 